\title{
A HIBRID KONFLIKTUSOK FELÍVELÉSI SZAKASZA, AVAGY A FENYEGETÉS ÉSZLELÉSÉNEK, MEGELŐZÉSÉNEK ÉS KEZELÉSÉNEK NEMZETBIZTONSÁGI ASPEKTUSAI
}

DOI: $\underline{10.35926 / H S Z .2020 .4 .4}$

ÖSSZEFOGLALÓ: A hibrid fenyegetések az állam müködéséhez elengedhetetlen funkciókat támadják a célországban. Az egyre intenzívebb és kiterjedtebb müveletek körülményeinek vizsgálata úgy tünik leginkább eredményesnek, ha ezeket a nemzetközi együttmüködésben és a jogalkotásban rejlö lehetöségekre figyelemmel végezzük el.

KULCSSZAVAK: jogalkotás, hibrid hadviselés, nemzetbiztonság

\section{BEVEZETÉS}

A tanulmány célja a hibrid fenyegetés észlelése, megelőzése és kezelése, nemzetbiztonsági aspektusainak vizsgálata és a megállapítások megjelenítése. A vizsgálat szintjeinek meghatározása során szükséges figyelmet fordítani a nemzetközi együttmüködésben és a jogalkotásban rejlő lehetőségekre is, és így megközelíteni ezt a többdimenziós fenyegetést.

Az ilyen jellemzőkkel rendelkező új típusú fenyegetettség jelenléte a nemzetközi színtéren egyre intenzívebb és kiterjedtebb. A hadviselő fél e tevékenységsorozat közben a modern technológiák által nyújtott lehetőségeket használja fel, és müveleteit kiterjeszti a gazdaságra, a médiára, a kibertérre és a társadalmi érintkezés különböző formáira is. Az egyes elemek (támadási formák) egyenkénti vagy egymást kiegészítő alkalmazása - a klasszikus támadási formák bevetése nélkül is - már alkalmas lehet a befolyásolásra, a zavarkeltésre, egyes államok belső rendjének a megbontására, a társadalmi tudat újraformálására. Az új típusú fenyegetettség fokozott szintjére tekintettel Magyarország kiemelt feladatként tekint a hibrid fenyegetések elleni fellépésre, illetve azok kezelésére.

A hibrid hadviselés nemzetbiztonsági aspektusból történő vizsgálatának egyik meghatározó eleme, hogy a professzionális jelző ${ }^{2}$ meghatározó voltát kétségbe vonja olyan szem-

\footnotetext{
A tanulmány a Magyar Katonai Jogi és Hadijogi Társaság megbízásából, a Honvédelmi Minisztérium által támogatott kutatás keretében készült.

2 Az ilyen, a hibrid hadviselés eszköztárába tartozó intézkedések mögött nem feltétlenül kell egy adott államot és annak hírszerző szolgálatát keresnünk, hiszen egy terrorszervezet, egy nem állami szervezet vagy a gazdasági élet befolyásos szereplői is képesek azokat végrehajtani, alkalmazni.
} 
pontból, hogy a tevékenység irányítójára foglalkozásszerü összeesküvőként tekint. Ez a fenyegetettség és a kitettség magasabb fokát jelenti, az ezzel szembeni küzdelemben tehát sokkal komolyabb erőforrásokat indokolt felhasználni, mint korábban képzelhettük.

Társadalmaink hibrid fenyegetések, rosszindulatú számítógépes tevékenységek és dezinformáció elleni védelmének fontosságát hangsúlyozza az EU új, 2019-2024 közötti időszakra vonatkozó stratégiai menetrendje ${ }^{3}$ is, továbbá kiemeli, hogy az ilyen veszélyek kezelése átfogó megközelítést igényel, több együttműködéssel, koordinációval, erőforrással és nagyobb technológiai kapacitás alkalmazásával.

\section{AZ EURÓPAI UNIÓ TAGÁLLAMAI KÖZÖTTI, HIBRID FENYEGETÉSEK ELLENI - RÉSZBEN MÁR KIÉPÍTETT - EGYÜTTMÜKÖDÉS AKTUÁLIS KÉRDÉSEI}

A hibrid fenyegetések belső biztonságra kifejtett hatását elsősorban tagállami kompetencia képes azonosítani és kezelni, viszont az elmúlt évek tapasztalatai alapján az is nyilvánvalóvá vált, hogy szükséges a közös, uniós fellépés és megközelítés kialakítása ezen a területen.

A tagállamok közötti ez irányú magas szintü együttmüködés a külügy- és a védelmi miniszterek 2019. augusztusi informális ülésén, ${ }^{4}$ illetve a 2019. szeptemberi Belső Biztonságra Vonatkozó Operatív Együttmüködéssel Foglalkozó Állandó Bizottság $\left(\mathrm{COSI}^{5}\right)$ ülésein is megerősítésre került, továbbá a Gazdasági és Pénzügyi Tanács $\left(\right.$ Ecofinn $\left.^{6}\right)$ informális ülése keretében a résztvevők megvitatták a pénzügyi szektor szerepét a hibrid fenyegetések elhárításában. ${ }^{7}$

A COSI szerepéről és összetételéről az Európai Unió működéséről szóló szerződés 71. cikke rendelkezik. A COSI az EU belső biztonságával kapcsolatban a tagállamok által kifejtett operatív tevékenységek koordinálását segíti, ösztönzi és erősíti. Feladatai:

- gondoskodik az EU belső biztonságát érintö ügyekben történő hatékony operatív együttmüködésről, többek között a bünüldözés, a határellenőrzés, valamint a büntetőügyekben folytatott igazságügyi együttmüködés területén;

- értékeli az operatív együttmüködés általános irányát és eredményességét;

- segítséget nyújt a Tanácsnak a terrormerényletekre vagy a természeti, illetve az ember okozta katasztrófákra történő reagálásban.

\footnotetext{
A 2019-2024-es időszakra szóló új stratégiai menetrend. Európai Tanács. https://www.consilium.europa.eu/media/39917/a-new-strategic-agenda-2019-2024-hu.pdf (Letöltés időpontja: 2019. 10. 27.)

4 Informal meeting of EU defence ministers, 28-29 August 2019, Helsinki. https://eu2019.fi/en/events/2019-08-28/ informal-meeting-of-eu-defence-ministers- (Letöltés időpontja: 2019. 10. 27.)

5 Standing Committee on Operational Cooperation on Internal Security. A tagállamok belügyminisztériumainak és igazságügyi minisztériumainak magas rangú tisztviselőiből, valamint a Bizottság és az Európai Külügyi Szolgálat (EKSZ) képviselőiből áll. Ülésein meghívásra az Europol, az Eurojust, a Frontex, a CEPOL és más érintett szervek képviselöi is részt vehetnek megfigyelőként.

6 Economic and Financial Affairs Council - Gazdasági és Pénzügyi Tanács, az ECOFIN-t, az uniós tagállamok pénzügyminiszterei alkotják. A gazdaságpolitika, a pénzügyi szolgáltatások szabályozása és az adózás terén felelős az Unió politikájának alakításáért.

7 EU finance ministers: closer attention must be given to hybrid threats. Press release, 03. 09. 2019. https://eu2019. fi/en/article/-/asset_publisher/eu-n-valtiovarainministerit-hybridiuhkiin-kiinnitettava-enemman-huomiota; Informal meeting of ministers for economic and financial affairs (Ecofin) and Eurogroup. https://eu2019.fi/en/ events/2019-09-13/informal-meeting-of-ministers-for-economic-and-financial-affairs-ecofin-and-eurogroup (Letöltések időpontja: 2019. 10. 26.)
} 
A résztvevők a fenti fórumok mindegyikén kinyilvánították az uniós szintü közös fellépésről és a fenyegetések pontos meghatározásáról szóló vita folytatásának igényét. Az álláspontok szerint az uniós ügynökségek, mechanizmusok és hálózatok területre történő bevonásának lehetősége kapcsán szükséges folytatni a vitát. Fontos szempont, hogy az érintett szereplők nemcsak a bel- és igazságügyi ügynökségek (pl. Europol, Frontex) között azonosíthatók, hanem például idevehető a Bizottság Vészhelyzeti Koordinációs Központja $\left(\mathrm{ERCC}^{8}\right)$ is.

A további viták szükségességét és a fogalmak tisztázásának elengedhetetlen voltát támasztja alá az is, hogy „, bár a hibrid fenyegetések fogalma nem állandó, és rugalmasnak is kell maradnia annak érdekében, hogy megfeleljen a jelenség változó jellegének, a koncepció célja, hogy megragadja azoknak a kényszeritö és felforgató tevékenységeknek, valamint hagyományos és nem hagyományos módszereknek (például katonai, diplomáciai, gazdasági, technológiai) az egyvelegét, amelyeket állami vagy nem állami szereplök összehangolt módon használhatnak fel bizonyos célok elérése érdekében úgy, hogy eközben a hivatalosan deklarált hadviselés szintje alatt maradnak."9

Az átfogó megközelítés lehetővé tenné, hogy a bünüldöző hatóságok és a polgári védelem konkrét tevékenységei integrálásra kerüljenek a hibrid fenyegetésekről szóló átfogó vitába. A releváns uniós ügynökségek és más uniós mechanizmusok szerepének meghatározása, valamint a hibrid fenyegetésekkel szembeni ellenálló képesség és felkészültség megerősítése a belső biztonsággal összefüggésben elősegíti a többi szereplővel történő együttmüködés fejlesztését, például a közös kül- és biztonságpolitika (KKBP) szereplöivel, valamint erősíti a belső-külső biztonsági kapcsolatokat.

Az idézett, 2016-os közös közlemény kiemeli továbbá azt a tanulmány szempontjából kiemelt jelentőségü körülményt, miszerint ,, a hangsúly általában a célpont sebezhetö pontjainak kihasználásán, valamint egy olyan, nem egyértelmü helyzet megteremtésén van, aminek célja a döntéshozatali folyamatok hátráltatása. A hibrid fenyegetések eszközei lehetnek eröteljes félretájékoztatási kampányok is, amelyek során a szociális médiát használják fel a politikai narrativa befolyásolása, vagy közvetitő szereplök radikalizálása, toborzása és irányítása céljából." 10

A dezinformáció - ami a hibrid fenyegetések kiemelt és veszélyes eszköze - új kihívások elé állítja a nemzetbiztonsági, rendészeti és egyéb hatóságokat, illetve szerveket, különös tekintettel az egyre inkább digitalizálódó világunk sajátosságaira. A dezinformálás erős fegyver azoknak az állami vagy nem állami szereplőknek a kezében, akik nyugtalanságot, elégedetlenséget, polarizációt és egyértelmü károkat akarnak okozni társadalmaink számára.

A dezinformáció elleni küzdelem területén az EU Grúziai Megfigyelő Missziója kiválóan hasznosítható tapasztalatokat szerzett, és az eredményeket alátámasztotta a Grúzia NATO-integrációját vizsgáló szakmai munkacsoport is. ${ }^{11}$ Ez ugyanis az orosz (gazdasági és politikai) térnyerés oldaláról közelíti meg Grúzia, Ukrajna, Moldávia és az „új kelet-európai EU-tagállamok" előtt álló kihívásokat, melyek - a Grigol Mgaloblisvili által vezetett mun-

\footnotetext{
${ }^{8}$ Emergency Response Coordination Centre.

9 Az Európai Parlamentnek és a Tanácsnak A hibrid fenyegetésekkel szembeni fellépés közös keretéről szóló közös közleménye. https://eur-lex.europa.eu/legal-content/HU/TXT/?uri=CELEX\%3A52016JC0018 (Letöltés időpontja: 2019. 10. 26.)

10 Uo.

${ }^{11}$ Grigol Mgaloblishvili et al.: Hybrid warfare and the changing security landscape in the Euro-Atlantic area - political and economic implications. Economic NATO Research Paper No 1, Tbilisi, Georgia, 2016.
} 
kacsoport által készített és a Nyílt Társadalom Grúziai Alapítványa (OSGF $\left.{ }^{12}\right)$ által finanszírozott tanulmány szerint - a szabadság és az emberi jogok veszélybe kerülésén keresztül jelennek meg.

A tanulmány megállapításai szerint ami a hibrid kihívásokat új jelenséggé teszi, az a nem katonai eszközök jelentőségének fontossága a müveletek során. A Mgaloblisvili és szerzőtársai által jegyzett mű szerint ez a hadviselésnek egy olyan modern formája, amely elsősorban a stratégiai célok elérésére összpontosít fizikai konfliktus igénybevétele nélkül, különösen a konfliktus kezdeti szakaszában. Ebbe illeszti be a jelentés a Grúzia elleni 2008-as orosz agressziót, melyet megelőzően provokációt, pszichológiai és lélektani hadviselést, valamint más incidenseket (jelentős létszámú, támadásra kész katonai erő határon történő összevonását) szenvedett el a grúz fél. Ugyanakkor az Európai Tanács felkérésére Heidi Tagliavini svájci diplomata vezetésével egy tényfeltáró testület azt állapította meg, hogy nem lehetett bizonyítani azokat a grúz állításokat, melyek szerint - a grúz offenzíva megkezdése előtt - nagyszámú, támadásra kész orosz fegyveres erö lett volna jelen Dél-Oszétiában, mint ahogy azt sem, hogy a grúz (megelőző) támadással csak a Dél-Oszétiába benyomuló orosz müveleteket kívánták volna megállítani. A szakértői testület ugyanakkor megállapította azt is, hogy az oroszok még a grúz offenzíva megindítása elött félkatonai alakulatokat vonultattak fel Dél-Oszétiában, és ezek az irreguláris csapatok aztán grúz falvakat támadtak meg, amelyeket az orosz békefenntartók „,nem akartak vagy nem tudtak” megvédeni. A hibrid fenyegetés karakteres ismérveit vélhetjük felfedezni az orosz müveletekben, illetve a grúzok talán csak eszközök voltak egy (néhány évvel későbbi) nagyobb projekt előtti teszt alanyaiként?

Lehet, hogy Grúzia után - mindenféle összefüggés nélkül - egyszerüen csak Ukrajna volt a soros a kevésbé szerencsés történelmi előzményekkel rendelkező országokat érő nagy nemzetközi politikai erőterek által generált játszmában, és ennek eredményeként az államot és polgárait érő veszteségek elszenvedésében.

A hibrid fenyegetések széles spektrumon jelentkeznek, és elsődleges kezelésük tagállami feladatkörbe tartozik, így az EU-intézmények, illetve -ügynökségek egyik legfontosabb célja az kell hogy legyen, hogy az egyes érintett szervek, szervezetek közötti koordinációt, illetve információk megosztását biztosítsák, továbbá az EU intézményeinek közvetlen védelmét ellássák. Fontos célkitüzés ezeken túl - különösen az ún. kiválósági központokon keresztül - a jelenség kutatása és hatékony védekezési eszközök kidolgozása is.

A gyakorlatban ez a munka az EU Hibrid Fúziós Központja ( $\left.\mathrm{HFC}^{13}\right)$, az Europol, a Frontex, az EU ERCC és más releváns szereplök, hálózatok, kiválósági központok által készített közös, hibrid fenyegetésekről szóló elemzői jelentés vagy értékelés formájában valósulhat meg. Ez közös jelzőrendszer létrehozását eredményezheti a hibrid fenyegetések hatékonyabb felderítése (leginkább monitorozása) és elhárítása érdekében. Ezek alapján az egyes érintett szervek, illetve szervezetek a már meglévő hatás- és feladatkörükben képesek arra, hogy a hibrid fenyegetés (elleni küzdelem) horizontális témaként erőteljesebben jelenjen meg. Emellett az uniós polgári védelmi mechanizmus platformként szolgálhat a szakértői csoportok számára az azonosított hibrid fenyegetésekre történő reagálás szempontjából is.

Az egyik legfontosabb EU-ügynökség a hibrid fenyegetések elleni küzdelem területén az EU Hírszerző és Helyzetértékelő Központja $\left(\right.$ INTCEN $^{14}$ ) - illetve benne a HFC - támogatja a tagállamok területén végzett munkáját. A fenyegetés egyre növekvő voltára tekintettel ugyan-

\footnotetext{
12 Open Society Georgia Foundation.

13 Hybrid Fusion Cell.

${ }^{14}$ Intelligence and Situation Centre.
} 
akkor javasolt lenne az egység kapacitásainak továbbfejlesztése, illetve szorosabb koordinációja a tagállami (hazai) rendvédelmi szervekkel, illetve nemzetbiztonsági szolgálatokkal.

A kapcsolatok és az együttmüködések megerősítésén túl szükséges azonban az összeurópai hatékonyság fokozása szempontjából a nemzeti szinteken is hasonlóan komplex és átfogó megközelítést meghonosítani mind a szabályozás, mind az intézmények, mind pedig a szervezetek közti együttmüködés terén a kormányzati koordináció viszonylatában. Ezek nélkül a nemzeti szinten kevéssé korszerü megoldások kapcsolódhatnak csak össze európai szinten, amelyek így a hátrányos (nem kívánt) hatásokat erősíthetik fel.

Az EU ügynökségeinek fontos szerepet szükséges betölteniük a kutatás, a koordináció és az információáramlás biztosításán túl egy irányadó és hiteles információs háttér kialakítása során is, mivel a hibrid támadások sok esetben célzottan az együttmüködés és a kölcsönös bizalom aláaknázására irányulnak. A kölcsönös bizalom gyengítése egy olyan spirálba taszíthatja a tagállamokat, melynek során a hatékony együttmüködés veszélybe kerül, és ezen keresztül az állam önvédelmi képessége is csökken.

A különböző uniós ügynökségek, kapcsolati rendszerek és mechanizmusok szerepe beazonosításának objektív előnye, hogy egyesíti és kihasználja az egyes erősségeket, hogy támogatja a hibrid fenyegetések felismerésére, azonosítására és leküzdésére irányuló átfogó és integrált megközelítést. Továbbá azt is szükséges megvizsgálni, hogy pontosan milyen eszközök használhatók fel a célzott dezinformációs és propagandakampányok vagy más hibrid befolyásolási módszerek kezelésére, valamint a mögötte álló szereplők azonosítására. Az előbb kiemelt bizalomcsökkentésre irányuló titkos intézkedések eredményeként érvényesülhetnek azok a professzionális tervek, amelyek egyes állami vagy nem állami szervezetek által végrehajtásra kerülnek.

Jogalkotási szempontból fontos szerepet játszanak az Európai Tanács mellett müködő horizontális hibrid fenyegetések és a dezinformációs munkacsoport is. Mivel a munkacsoport közvetlenül az Állandó Képviselők Bizottsága $\left(\right.$ Coreper $\left.^{15}\right)$ alatt müködik, alkalmas lehet a hibrid fenyegetések elleni EU-szintü kezdeményezés, illetve tevékenység koordinálására. Magyarország álláspontja szerint támogatható lenne ugyanakkor egy szakértői alcsoport kialakítása, amelyben a tagállamok felelős szolgálatai képviseltetnék magukat előkészítve, illetve segítve a munkacsoport munkáját. Fontos szerepe lehet továbbá az uniós szintü eröfeszítések elősegítése terén az EU támogatásával Helsinkiben létrejött Hibrid Fenyegetések Elleni Kiválósági Központnak, amelyhez Magyarország csatlakozásának elökészítése a tanulmány készítésekor már folyamatban, mondhatni célegyenesben van. A Központ jelentőségét növeli, hogy a NATO támogatását is magáénak mondhatja, elég csak a PACE17 kibergyakorlat végrehajtására gondolnunk.

Megfontolásra érdemes lehet egy olyan állandó rendszer kialakítása, amely a megszerzett adatok elemzése és a tájékoztató tevékenység elvégzése mellett - vagyis azon túl - uniós szinten összefogná és koordinálná a hibrid fenyegetésekkel foglalkozó csoportok, szervezetek munkáját.

Miként a 2018. június 13-án Brüsszelben kiadott közös nyilatkozatban ${ }^{16}$ is külön hangsúlyt fektettek a hibrid fenyegetések átfogó helyzetképének és a tudatosság uniós szintü

\footnotetext{
15 Comité des représentants permanents.

16 Joint Communication to the European Parliament, the European Council And the Council - Increasing resilience and bolstering capabilities to address hybrid threats. 13. 06. 2018. https://eeas.europa.eu/sites/eeas/files/ joint_communication_increasing_resilience_and_bolstering_capabilities_to_address_hybrid_threats.pdf (Letöltés időpontja: 2019. 10. 26.)
} 
továbbfejlesztésének szükségességére, megállapítható, hogy e célok nem veszítettek aktualitásukból a mai napig sem.

Az előbbi gondolatot támasztja alá még a hibrid fenyegetések sajátos természete is, hiszen azok gyakran fokozatosan, idővel és lépcsőzetesen valósulnak meg, továbbá többféle módszer kombinációjából állnak. A releváns fenyegetések - időben történő - észlelésének és elemzésének fontosságát is szükséges kiemelni, hiszen ha terv szerint lépcsőzetesen szenved el hibrid intézkedéssorozatot egy adott tagállam, és nem fedezi fel időben, hogy mi zajlik le éppen, akkor annak súlyos társadalmi, nemzetgazdasági következményei lesznek.

Korábban kiemelésre került az EU INTCEN és különösen az annak részét képező HFC munkája, amely értékeli a hibrid fenyegetéseket, valamint helyzetértékelést nyújt az ellenséges hibrid szereplők által okozott fenyegetésről. Ezzel szoros összefüggésben nemzeti szinten is meg kell valósítani a hírszerző szolgálatokkal történő magasabb szintü és erőteljesebb kooperációt. Ezt leginkább a tagállamok felelősségének erősítésével, illetve növelésével, valamint a meglévő eszközök alkalmazásának fokozásával és a párhuzamosságok elkerülésével lehet hatékonnyá tenni, kiemelt figyelemmel a bünüldöző és a hírszerző szolgálatok közötti együttmüködésre, a polgári védelem bevonására és a magánszférával történő kooperációra is. Rendvédelmi megközelítésben a külső határok védelme szempontjából is érdemes vizsgálni az Európai Uniót érő hibrid fenyegetéseket. Valós veszélyt jelenthet ugyanis, hogy a fenyegetéseket kitervelö, illetve megvalósító személyek a bevándorlási hullámokat is számításba vehetik, így a határőrizet terén is megjelenik a hibrid kockázatok elleni közös fellépés szükségessége.

Az ellenérdekelt szereplők ugyanis dezinformációs müveletekkel kombinálva felhasználhatják a migrációs áramlásokat a migrációellenesség gerjesztésére is, vagy éppen az illegális migráció ellen jogszerüen fellépő tagállamok - különösen határvédelmi célú - intézkedésre kényszerítésével alkalmas az azokkal szembeni (hazai, illetve nemzetközi) bizalom csökkentésére. Így egy jól kidolgozott hibrid fenyegetés egyik intézkedése lehet olyan tartalmú dezinformáció eljuttatása valamelyik államhoz, amely eredményeként az állam valamely addig nem megerősített „,másik” határszakaszára jelentős védelmi erőket csoportosít át, akár sok milliárd forintnak megfelelö kiadást okozva.

Az elmúlt időszak tagállami szintű tapasztalatai alapján kijelenthető, hogy elsősorban a választások tisztasága és a detektált dezinformációs müveletek kapcsán merültek fel hibrid fenyegetésekre utaló jelek. A nemzeti hatóságok álhírekkel szembeni sürgős fellépése során az EU-nak is hangsúlyos szerepet kell vállalnia a tagállamok támogatásában, mivel a múveletek elsődlegesen a tagállamok ellen irányulnak, azok kormányzatának „,megtámadása” által.

A közös fellépés kapcsán meg kell említeni - főleg, ha NATO-tagállamban élő személyként igyekszünk értelmezni az Európai Unió müködéséről szóló szerződés ${ }^{17}$ (EUMSZ) 222. cikkét -, hogy a szolidaritási klauzula egyáltalán nem feleltethető meg az Észak-atlanti Szerződés 5. vagy 6. cikkében leírtaknak, ugyanakkor érdemes összevetni ezeket.

Az EUMSZ 222. cikke alapján ha egy tagállamot terrortámadás ér, illetve ha természeti vagy ember okozta katasztrófa áldozatává válik, akkor az EU és tagállamai a szolidaritás szellemében együttesen lépnek fel. Az Unió minden rendelkezésére álló eszközt - ideértve a tagállamok által rendelkezésre bocsátott katonai erőforrásokat is - mozgósít annak érdekében, hogy:

\footnotetext{
${ }^{17}$ Az Európai Unióról szóló szerződés és az Európai Unió működéséről szóló szerződés egységes szerkezetbe foglalt változata. 2012. 10. 26. https://eur-lex.europa.eu/legal-content/HU/TXT/?uri=celex\%3A12012E\%2FTXT (Letöltés időpontja: 2020. 05. 15.)
} 
- megelözze a terrorista fenyegetést a tagállamok területén, megvédje a demokratikus intézményeket és a polgári lakosságot egy esetleges terrortámadástól, terrortámadás esetén egy tagállamnak - a politikai vezetése kérésére - annak területén segítséget nyújtson;

- természeti vagy ember okozta katasztrófa esetén egy tagállamnak - a politikai vezetése kérésére - annak területén segítséget nyújtson.

Tehát amennyiben egy tagállam olyan hibrid fenyegetés áldozatává válik, melynek egyfajta eszközcselekménye, vagyis egyik intézkedése egy nukleáris erőmű túlmüködését eredményezné (például egy kibertámadás eredményeképpen), akkor alkalmazhatóvá válna az említett szolidaritási klauzula az uniós és tagállami képességek és válaszlépések együttes alkalmazása érdekében.

Véleményem szerint a katasztrófaelhárítás és a polgári védelem szemszögéből elsődlegesen a hibrid hadviselés eredményeként megjelenő negatív hatások leküzdése és a károk csökkentése jelenhet meg legfontosabb célként, míg az Europol a bünüldözés oldaláról vizsgálja meg a fenyegetettség kérdéskörébe tartozó jelenségeket. Mivel az Europol alapvető célja a súlyos nemzetközi büncselekmények és a terrorizmus elleni fellépés, emiatt újra megfigyelhetővé válik, hogy a hibrid hadviselés esetkörébe tartozó egyes intézkedések, eszközök, valamint adott esetben a végeredmény jelentette büncselekmény tartozik a feladatkörébe, de a bünüldöző hatóságok törvényekben meghatározott hatáskörébe nem tartozó információgyüjtő tevékenység nem feltétlenül. ${ }^{18}$

Az Europol szempontjából a hibrid fenyegetettség megnyilvánulási formái, eszközei lehetnek a kiberbünözés, a terrorizmus, a szervezett bünözés, ${ }^{19}$ valamint a tömeges illegális migrációs áramlatok, utóbbiak esetén kiemelten az embercsempészettel összefüggő büncselekmények elkövetése. Az Europol a feladatrendszere alapján az EU tagállamainak erre irányuló konkrét igénye esetén tud segítséget nyújtani egy átfogó helyzetértékelés elkészítése, müszaki-technikai eszközökkel történő hozzájárulás és kooperációt elősegítő egyéb tevékenységek által. A magyar kormány által képviselt álláspont szerint ezért (is) kell belső biztonsági és bünüldözési szempontból kiemelt figyelmet fordítani a terrorizmus és a migráció olyan típusú összefüggésére, melynek során a terrorista szervezetek migrációs áramlások kihasználására törekszenek.

Norvégia ugyan nem EU-tagállam, így az előbbi következtetéseket, ismertetett mechanizmusokat, intézményeket és ügynökségeket nem tekintheti a közösség részeseihez hasonlóan magáénak. Értelemszerűen azonban nem okoz meglepetést, hogy az EU-tagállamok által detektált, illetve a NATO-tagállamok között megosztott hibrid fenyegetés jelentette kihívásokat ismerve - és a 2019. szeptemberi helyhatósági választásokra készülve - külön protokollt dolgozott ki a dezinformáció (kiemelten a választások nemkívánatos befolyásolásának) elhárítására. Mivel a NATO-tagállam Norvégia nem érzékelt eddig komolyabb és

${ }_{18}$ Work programmes. Europol, 04. 11. 2016. https://www.europol.europa.eu/publications-documents/work-programmes (Letöltés időpontja: 2019. 10. 27.)

19 A szervezett bünözés és a különleges katonai (hírszerzési) müveletek összefüggései témában bővebben lásd Norman Lewis: The Honored Society. Collins, London, 1964.; Monte S. Finkelstein: Separatism, the Allies and the Mafia: The struggle for Sicilian Independence. Lehigh University Press, Cranbury, 1998.; John Dickie: Cosa Nostra - a history of the Sicilian Mafia. Hodder and Stoughton, London, 2004.; Alfio Caruso: Da cosa nasce cosa Storia della mafia dal 1943 a oggi. Longanesi, Milano, 2005.; Kaputa László: Fejezetek a maffia történetéből. Szakmai Szemle, 2011/1., 23-57. https://www.knbsz.gov.hu/hu/letoltes/szsz/2011_1_szam.pdf (Letöltés időpontja: 2020. 05. 15.) 
konkrét hibrid fenyegetést, ezért azt megelőzően a rendvédelmi szervek nem is folytattak konkrét, célirányos felkészülést a korábbi népképviseleti választások előtt, ellentétben egyes EU-tagállamokkal, amelyek (éppen) emiatt már rendelkeznek tapasztalattal ezen a téren. Norvégia nem zárta ki az orosz hátterü befolyásolási szándékot, emiatt az elővigyázatosság feltétlenül indokolt volt. Kijelenthetö, hogy a felkészületlenség, a fenyegetés fel nem ismerése vagy bagatellizálása minden esetben a hibrid fenyegetés jelentette kockázatot növelö, az esetleges idegen hibrid intézkedés eredményességét növelö környezetet eredményez.

A NATO fötitkára, a norvég Jens Stoltenberg 2019. július 17-én a Coloradóban rendezett Aspen Security Forumon tett nyilatkozatában ${ }^{20}$ a Szkripal-ügy kapcsán mondottak között elöadta, hogy az ügynököt egy NATO-tagállam területén vetették be, ami a demokratikus folyamatokat és választásokat is veszélyeztető hibrid fenyegetéseknek nevezett tevékenységek sorába tartozik. Korábban a határokon áthaladó hadseregek, rakéták jelentettek veszélyt a Szövetség tagállamaira, de ez mára jelentősen megváltozott. Kiemelte, hogy például a kibertámadások esetén még azt sem tudjuk, hogy ki a támadó. Álláspontja szerint kiber- és hibrid támadások nap mint nap előfordulnak. Ezt jól ismerik a NATO-tagállamok (elhárító) szakmai tevékenységet végző szervei, egy végrehajtott (elhárító) intézkedési sorozatra szolgál példaként a Norvégia által megvalósított dezinformáció elleni akcióterv.

A speciális intézkedéssorozatot a norvég Önkormányzati és Modernizációs Minisztérium munkatársai vezették, együttmüködve a Nemzetbiztonsági Hatósággal $\left(\mathrm{NSM}^{21}\right)$, a Társadalombiztosítási és Felkészültségi Igazgatósággal, a Választási Igazgatósággal, a Rendőrségi Titkosszolgálattal ( $\mathrm{PST}^{22}$ ), a Védelmi Minisztériummal, az Igazságügyi és Közbiztonsági Minisztériummal, a Külügyminisztériummal, a Hírszerző Szolgálattal (E-tjenesten $^{23}$ ) és a Médiahatósággal.

A kidolgozott terv legfontosabb pontjai az alábbiak voltak:

- a norvég kormányzat a Választási Igazgatósággal, az NSM-mel, a PST-vel és az E-tjenestennel együttmüködve elvégezte a választások lebonyolításához szükséges biztonsági kockázatelemzéseket;

- az NSM, a PST és az E-tjenesten közös figyelemfelkeltő brossúrát készített, melyet minden, a 2019. évi önkormányzati és megyei önkormányzati választáson induló jelöltnek megküldtek, és amelyben többek közt tájékoztatták a jelölteket a helyes adatvédelmi eljárásokról, az elektronikus információbiztonság alapvető fogásairól;

- a PST szakmai tanácsadást nyújtott a politikai pártoknak, a köztisztviselőknek és egyéb érintett személyeknek;

- a 2017. évi parlamenti választás előtt az NSM létrehozott egy, a közösségi médiára vonatkozó információbiztonsági szolgáltatást, amely a 2019. évi választások idején azt a célt szolgálta, hogy megnehezítse a központi hatóságok és a köztisztviselök profiljának feltörését, emellett lehetővé tette az irányítás gyors visszavételét, ha a fiókokat mégis feltörnék, továbbá a hatósági személyeknek tulajdonított közlések sokkal súlyosabb hatására tekintettel külön figyelmet fordítottak arra, hogy illetéktelen

\footnotetext{
${ }^{20}$ Jan Kalvik: Secretary General at Aspen Security Forum: NATO is good for Europe and North America. Defence and Intelligence Norway, 19. 07. 2019. https://www.etterretningen.no/2019/07/19/secretary-general-at-aspen-security-forum-nato-is-good-for-europe-and-north-america/ (Letöltés időpontja: 2019. 10. 29.)

${ }^{21}$ Nasjonal sikkerhetsmyndighet.

${ }^{22}$ Politiets sikkerhetstjeneste.

${ }^{23}$ Etterretningstjenesten.
} 
személy ne adhassa ki magát a központi hatóságok képviselőjének vagy köztisztviselőnek a közösségi médiában;

- a Választási Igazgatóság felkészítette a szavazás lebonyolításáért felelős állampolgárokat a választásokon alkalmazott müszaki-informatikai eszközök, programok használatára, valamint a kapcsolódó információbiztonsági követelmények betartására (alaposan megismertette velük);

- az Önkormányzati és Modernizációs Minisztérium felmérést végzett arra vonatkozóan, hogy az információk miként lennének befolyásolhatók a választási eljárás során;

- a Médiahatóság szemináriumot tartott a médiában elhangzó információk kritikus kezeléséről és az álhírekről;

- a Médiahatóság a választásokkal kapcsolatban kampányt folytatott ,,az álhírek felismerése" témában, és képzéseket tartott a szociális médián keresztül történő politikai befolyásolás témakörében.

A feladatterv áttanulmányozása eredményeként kijelenthető, hogy a NATO főtitkára által (is) kiemelt demokratikus (jog)intézmények elleni támadás kivédése során az egyik legfontosabb védendő érték a hitelesség megőrzése, az idegen dezinformációs műveletek elhárítása, illetve a fake newsok terjedésének megelőzése, akadályozása, korlátozása útján.

Más szemszögből vizsgálva természetesen megállapítható, hogy a hibrid támadások legjelentősebb célpontjai a választások tisztaságába vetett (hazai és nemzetközi) bizalom csökkentése és a demokratikus (jog)intézmények tekintélyének aláásása, rombolása. Ezt minden kormányzatnak figyelembe kell vennie a saját védelmi igazgatási struktúrájának kialakításakor.

Kovács Krisztián készítette el a védett értékek és az ezek elleni intézkedések tipizálását, mely alapján teljeskörüen átláthatóvá válik a kihívás e szegmensének rendszere:

„a) kompromittálás (ideológiai alapon, zsarolással, lojális alapon):

- titkosszolgálati információgyüjtés a gyenge pontok, befolyásolási lehetöségek felmérése érdekében;

- aktív titkosszolgálati müveletek a döntési mechanizmusok befolyásolására;

- politikusok, államigazgatási döntéshozók, eröszakszervezeti (fegyveres testületi) vezetök, kulcspozíciót betöltő személyek megvesztegetése, zsarolása, befolyásolása;

- a célország gazdasági teljesitöképességét meghaladó, veszélyeztetö üzleti kapcsolatok kialakitása;

b) felforgatás:

- a politikai elit hiteltelenitése;

- ellenzéki pártok, mozgalmak megszervezése, megerösitése, pénzügyi, ideológiai támogatása, a politikai status quo megbontása;

- az agresszorhoz lojális személyek, mozgalmak, szervezetek megtalálása/létrehozása és müködtetése;

- politikai, etnikai, vallási, társadalmi feszültségek szitása, szeparatista, elégedetlenségi mozgalmak létrehozása, erősitése;

- a célország nemzetközi kapcsolatainak befolyásolása, szövetségesi kapcsolatainak fellazítása;

- bünözői csoportok támogatása, a közrend megzavarása érdekében történö felhasználása;

c) szabotázsakciók rejtett titkosszolgálati támogatása (terrortámadások, infrastruktúra rongálása, rombolása, kibertámadások); 
d) propaganda:

- a célországban médiapozíciók megteremtéselátvétele, propaganda-és dezinformációs tevékenység meginditása;

- a közvélemény/közgondolkodás formálása, befolyásolása;

- a nemzetközi közvélemény befolyásolása;

e) dezinformáció (megtévesztés)."24

A tanulmány tárgya szerinti szempontból kiemelt fontossággal bíró rendszerezés, a hibrid fenyegetések egyik legveszélyesebbike, az idegen befolyásolás elleni védekezés (kémelhárítási aspektusú) struktúraváltozását indukálhatja, ami elősegítheti a nemzetbiztonsági szolgálatoknak a jelenleginél is intenzívebb, produktívabb együttmüködését.

\section{A HIBRID FENYEGETÉSEK ELLENI KÜZDELEM NEMZETI ESZKÖZRENDSZERÉT PRÓBÁRA TEVÖ KIHÍVÁSOK}

A bűnüldözési feladatrendszerrel szemben a nemzetbiztonsági funkció - érdemben - előzetes felderítést, illetve proaktív tevékenységet végez mind a környezet, mind a fenyegetések tekintetében. Ezzel a biztonság fenntartása és garantálása (fenyegetés elhárítása) mellett tágabb értelemben is erősíti és előmozdítja a nemzeti érdekek érvényesítését - ideértve akár az ún. befolyásolást is -, tehát rendeltetésében, feladatát tekintve és ebből adódóan eszközrendszerében és hatásköreiben is eltér a védelmi szféra többi ágazatától, ahogy ezt a nemzetbiztonsági szolgálatokról szóló 1995. évi CXXV. törvény indokolása is az alábbiak szerint rögzíti:

„Az államok nemzetbiztonsági érdekeik védelme és más nemzetek szándékainak megismerése érdekében igénybe veszik a nemzetbiztonsági szolgálatok sajátos, más szervezetek által nem helyettesithetö lehetöségeit.

Az alapvetöen titkos és rá jellemzö ${ }^{25}$ eszközöket felhasználó nemzetbiztonsági tevékenység megfelelö jogi szabályozást igényel annak érdekében, hogy semmilyen körülmények között ne jelenthessen veszélyforrást a demokratikus jogrendre, ezen belül az állampolgári jogokat csak akkor és olyan mértékben korlátozhassa, amennyiben az az ország nemzetbiztonságának megóvása, szuverenitásának érvényesitése céljából szükségszerü és indokolt." 26

Magyarország Alaptörvénye rendelkezik arról, hogy a nemzetbiztonsági szolgálatokat a kormány irányítja, ${ }^{27}$ a szervezetükre, müködésükre vonatkozó részletes szabályokat, a titkosszolgálati eszközök és módszerek alkalmazásának szabályait, valamint a nemzetbiztonsági tevékenységgel összefüggő szabályokat sarkalatos törvény ${ }^{28}$ határozza meg.

${ }^{24}$ Kovács Krisztián: A befolyásolás szerepe a modern hadviselésben. Felsőfokú Nemzetbiztonsági Tanfolyam évfolyammunka, Nemzeti Közszolgálati Egyetem, Budapest, 2018, 32-33.

${ }^{25}$ Figyelmet érdemlő körülmény, hogy előbbiek rögzítésének évében, 1994-ben a leginkább a nemzetbiztonsági szolgálatok eszközrendszerében elhelyezkedő képességek, ismeretek és alkalmazások jelenleg széles körben kerülnek felhasználásra a nem állami, ún. magán hírszerzési tevékenységet végzö (különösen a jelentös ipari, gazdasági) szereplők által is, így ma már nem beszélhetünk kizárólag állami felhasználókról ezen eszközök tekintetében.

${ }^{26}$ A nemzetbiztonsági szolgálatokról szóló 1995. évi CXXV. törvény általános indokolása alapján.

${ }^{27}$ Magyarország Alaptörvénye (2011. 04. 25.). 46. cikk. (4) bek. https://net.jogtar.hu/jogszabaly?docid=a1100425. atv (Letöltés időpontja: 2020. 05. 15.)

${ }^{28}$ Magyarország Alaptörvénye: 46. cikk (6) bek. Az Alaptörvény A nemzetbiztonsági szolgálatokról szóló 1995. évi CXXV. törvényre utal. 
A kialakított struktúrában a nemzetbiztonsági szektormodellek ${ }^{29}$ vizsgálata alapján a hazai szolgálatok vonatkozásában megfigyelhető, hogy még mindig érvényesül a konkuráló szolgálatok közötti korlátozott együttmüködés. Az ennek eredményeként megismerhető esetleges hátrányok ${ }^{30}$ egy kormányzati igazgatási szerv koordinatív funkciójával volnának ellensúlyozhatók, míg a vetélkedő jelleg erősségei hatékonyabban kihasználhatóvá válhatnak a megfelelö elemzést, értékelést felhasználó gyakorlati müködéssel.

Ezzel összefüggésben célszerü megvizsgálni a hírszerzési ciklus egyik legfontosabb lépését: a tájékoztató tevékenységet. ${ }^{31}$ A kormányzati funkciók stratégiai szintű irányítása és a politikai döntések meghozatala szempontjából meghatározó és egyben az idegen hibrid kihívást külföldön detektáló, vagy nemzeti hibrid képességet alkalmazó, hírszerző tevékenységgel foglalkozó nemzetbiztonsági szolgálatok számára egyfajta objektív értékméröként is felfogható, illetve alkalmazható. A szervezetek által végzett tájékoztató tevékenységet azonban a több szervezetre épülő rendszerekben illeszteni kell a kormányzati tevékenységek hatékonyságát növelő racionalizálási igényekhez, államreform-törekvésekhez, ideértve a visszajelzések helyes értékelésének elengedhetetlen voltát is.

A kormányzatot tájékoztató tevékenység végzésekor jelentősen növelhető annak hatékonysága, amennyiben a hírszerző szolgálatok információit koordináltan hasznosítják, különösen a párhuzamosságok elkerülése és a preferenciák egyértelmü meghatározása eredményeként. Ez elengedhetetlenül szükséges minden hibrid kihívás elleni, offenzív hírszerző feladat végrehajtásához füződő, stratégiai szintü döntéshozatali eljárás végigviteléhez. Nehezen képzelhető el a megfelelő tájékoztató tevékenység és az e tapasztalatok nyomán létrejövő döntésirányítási rendszer nélkül aktív befolyásoló művelet, vagyis saját hibrid tevékenykedés végzése is. A hibrid kihívások kapcsán érdemes megjegyezni, hogy - mint a nemzetközi együttmüködés során felvázolt gondolatok is mutatják - szoros együttmüködés, koordináció nélkül a hibrid kihívások ellen sem lehet hatékonyan fellépni, de ilyen, kompromisszumok eredményeként kialakított egységes és erős szakmai háttér hiányában ez az eszközrendszer esetleges alkalmazása is kudarcra van ítélve.

Hiszen önállóan hiába képes félmegoldásokra egy jól felkészült szakembergárda, ha teljeskörüen müködő és eredményes teljesítményt nem képes elérni. Nem szabad elfeledni a kihívásokra adandó válaszok keresésekor, hogy „,...A globális biztonsági környezetben zajló változások következtében felértékelödik a hírszerzés és az elháritás szerepe. A müveleti területre jellemzö összetett kihívások, valamint a gyakran változó biztonsági helyzet szintén megnöveli a pontos és időbeni információk és értékelések iránti igényt." 32

A széles körben nyilvánossá vált események körülményeiből, valamint az eddig leginkább a történelmi ismereteinkből és a saját életünk során megszerzett tapasztalatainkból levont tanulságok, következtetések alapján kijelenthető, hogy a hibrid hadviselés mint nem katonai, illetve katonai tevékenység jelentős költségvonzattal jár. Így hazánk esetében „,ki-

${ }^{29}$ Dr. Héjja István: Nemzetbiztonsági szervezeti modellek. In: Dobák Imre (szerk.): A nemzetbiztonság általános elmélete. NKE Nemzetbiztonsági Intézet, Budapest, 2014, 57-72. http://m.ludita.uni-nke.hu/repozitorium/bitstream/handle/11410/8567/Teljes\%20sz\%c3\%b6veg\%21?sequence=1\&isAllowed=y (Letöltés időpontja: 2020. 05. 15.)

30 Uo. 63.

${ }^{31}$ Dr. Vida Csaba: Korszerü elemző-értékelő eljárások alkalmazása a hírszerzésben. Hadtudomány, 2013/1-2., 77-86. http://www.mhtt.eu/hadtudomany/2013/1_2/HT_2013_1-2_mhtt.pdf (Letöltés időpontja: 2020. 05. 15.)

32 Szentgáli Gergely: Csendben szolgálni, 1. rész: A magyar nemzetbiztonsági szektor helyzete és átalakítása 2010 és 2014 között. Hadtudomány, 2015/1-2., 52. http://www.mhtt.eu/hadtudomany/2015/1_2/2015_1_2_4.pdf (Letöltés időpontja: 2020. 05. 15.) 
emelt jelentősége van annak a szempontnak, hogy a »korlátozott eröforrásokkal « rendelkezö államok esetében a nemzetbiztonsági struktúrák hatékony müködtetése, a koordinációs, irányitási, a technikai és az emberi erőforrásokra épülö információgyüjtö, az elemzö-értékelö, vagy akár a különbözö szakértői területek összehangolt munkája" 33 ténylegesen összeadódjon, és így kerüljön felhasználásra akár a hibrid kihívások elhárítása, akár hazánk nemzetbiztonsági érdekeinek érvényesítése során.

A mintegy 10 éve tartó, az egész védelmi ágazatot érintő struktúra- és feladatváltozások vizsgálatának eredményeként megállapítható, hogy hazánk sem kerülhette ki azt a nemzetközi tendenciát, amely főként a terrorizmus, a hibrid fenyegetések és a kibertérből érkező támadások elleni küzdelem, valamint a migráció kezelésének terén egy megújulási, átalakulási folyamatot sürgetett a védelem szervezése, képességfejlesztése és irányítása terén. ${ }^{34}$ Ez a folyamat a tanulmány tárgya szerinti témakörben még nem ért véget, jelenleg is tart.

A hibrid kihívások kezelését célzó kormányzati stratégia alapvetéseinek kidolgozása megkezdődött, illetve Magyarország már 2016-ban létrehozta a Terrorelhárítási Információs és Bünügyi Elemző Központot (TIBEK), amely figyelemmel kíséri és a rendelkezésre álló valamennyi adat felhasználásával folyamatosan elemezi Magyarország nemzetbiztonsági, bünügyi és terrorfenyegetettségi helyzetét. A TIBEK ezáltal kiemelkedően fontos szerepet képes betölteni a hibrid kihívások elleni küzdelem támogatása során, ugyanakkor feladatés jogkörének törvényi restrikciói alapján érdekérvényesítő müveletben nem (lehet) képes önállóan részt vállalni. Amint az Uniós gyakorlatban elért eredmények kapcsán megfigyelhettük, az információáramlás biztosításának és a speciális információkat tartalmazó adatbázisok létrehozásának kiemelt szerepe van a hibrid hadviselés elleni küzdelemben. Azt azonban nem szabad elfelednünk, hogy egy (tag)államnak nem kizárólag a védelemre kell összpontosítania. Egy ország nem rendezkedhet be kizárólag védelemre úgy, hogy majd a közösség megvéd a külső hatásoktól, különösen mivel tudnunk kell, hogy abban az esetben hiába van sok szövetségesünk, ha kevés a barátunk. Az önvédelem eszközrendszere elemei-

33 Dobák Imre: Nemzetbiztonsági szolgálatok - Betekintés a visegrádi országok (V4) nemzetbiztonsági rendszereibe. Hadtudomány, 2015/4., 114. https://epa.oszk.hu/02400/02463/00029/pdf/EPA02463_hadtudomanyi_szem1e_2015_04_113-130.pdf (Letöltés időpontja: 2020.05. 16.)

${ }^{34}$ Már elöljáróban kiemelhető, hogy összehangolt védelmi müködést és irányítást szolgáló megoldásokat nemzetközi összehasonlításban is megfigyelhetünk, amelyek közül talán legtöbben az Amerikai Egyesült Államokban működő mintát tekintik zsinórmértéknek. Emellett azonban fontos megjegyezni azt is, hogy a hazai szakmai-tudományos gondolkodásban is elindult ennek az irányvonalnak a kibontakoztatása. A külföldi megoldások és különösen az amerikai minta kapcsán lásd Béres János (szerk.): Külföldi nemzetbiztonsági szolgálatok. Zrínyi Kiadó, Budapest, 2018, 66-79.; Sáfrán József: Az Amerikai Egyesült Államok és Magyarország nemzetbiztonsági szervezetrendszerének összehasonlító elemzése. Felderítő Szemle, 2018/1. szám, 71-87. https://www. knbsz.gov.hu/hu/letoltes/fsz/2018-1.pdf;

A koordinált és hatékonyabb védelemszervezés és irányítás vonatkozásában lásd Keszely László: A védelmi igazgatás szerepe a nemzeti szintü átfogó megközelítés megvalósításában. Nemzeti Közszolgálati Egyetem, doktori értekezés, Budapest, 2017. https://nkerepo.uni-nke.hu/xmlui/bitstream/handle/123456789/12398/ertekezes. pdf;jsessionid=6A54F0AA7F3328F7F72B10F4636C9506?sequence=1; Lakatos László - Varga Attila Ferenc: A magyar honvédelmi igazgatás. In: Farkas Ádám - Kádár Pál (szerk.): Magyarország katonai védelmének közjogi alapjai. Zrínyi Kiadó, Budapest, 2016, 159-211.; Farkas Ádám: A védelmi kötelezettségtöl a fegyveres védelem rendszeréig. Katonai Jogi és Hadijogi Szemle, 2018/1., 7-28. https://epa.oszk.hu/02500/02511/00008/ pdf/EPA02511_katonai_jogi_szemle_2018_1_007-028.pdf; Farkas Ádám: Gondolatok az állam fegyveres védelmének lehetséges intézmény-fejlesztési irányairól. Katonai Jogi és Hadijogi Szemle, 2017/1-2., $103-124$. http://www.hadijog.hu/wp-content/uploads/2018/05/Katonai-szemle-2017-1-2.pdf (Letöltések időpontja: 2020. 05. 16.); Farkas Ádám: Az állam fegyveres védelmének alapvonalai. Budapest, Katonai Nemzetbiztonsági Szolgálat, 2019. 
nek meghatározása egészen más megközelítést igényel, mint a közös, EU- vagy NATO-szerepvállalásunk során nyújtott hozzájárulásunk egyes részcselekményei, miként egy ország védelme is egészen más nézőpontot és megoldásokat igényel, mint egy szövetségé.

Érdemes vizsgálat tárgyává tenni azt az aspektust is, hogy egy országnak a nemzeti érdekek érvényesítése céljából számításba kell vennie az aktív cselekvés lehetőségeinek megvalósíthatóságát is, ha nem akar végzetes lemaradásba kerülni ebben a láthatatlan versenyben.

A jogszabályi háttér megteremtése vonatkozásában annak kiemelt jelentőségét hangsúlyozza Szabó Károly is tanulmányában, miszerint: „A befolyásolási müvelet és az abban alkalmazott eszközök - kompromittálás, propaganda, dezinformáció, felforgatás -, a hibrid fenyegetések az állam müködéséhez szükséges funkciókat támadják a célországban. Az egyetlen kézenfekvö megoldásnak az tünik, ha a kémelháritás az államilag irányított politikai, katonai, gazdasági, társadalmi, információs, infrastrukturális és titkosszolgálati befolyásolás teljes vertikumának lefedésére törekszik. Egy állam részéről a »vegytiszta «irszerzö tevékenység meghaladása, a hihetö tagadás lehetősége és a technikai, az infokommunikációs eszközök kontroll nélküli alkalmazása szinte ellehetetleníti a kémkedéssel szembeni büntetőjogi szankcionálást.",35

A hibrid fenyegetések elleni küzdelem és a nemzeti érdekek speciális eszközökkel történő érvényesítése során ugyanis egyaránt fontos a nemzetbiztonsági szolgálatoknak a megfelelö jogkörökkel, tárgyi eszközökkel és személyi állománnyal történő ellátása. Ha ezek egyike hiányzik, akkor a szakmai tevékenységük sikertelenségre van ítélve.

A hibrid fenyegetések megelőzése, felderítése és az előbbiekhez kapcsolódó intézkedések kezdeményezésének összetett feladatrendszere - melyek közül külön szükséges kiemelni a koordináció és kooperáció részfeladatait - generálisan nem telepíthető (csak) egy kiválasztott nemzetbiztonsági szolgálathoz. Megítélésem szerint egy ilyen koncepció a tárcaközi koordinatív funkció (lehetőségének) hiányában csak korlátozott sikerrel kecsegtethet.

A hibrid hadviselés elleni küzdelem során kiemelt jelentőséggel bíró figyelemfelhívásra helyezve a hangsúlyt megállapítható, hogy hazánkban ezt a tevékenységet elsődlegesen az Alkotmányvédelmi Hivatal, az Információs Hivatal és a Katonai Nemzetbiztonsági Szolgálat végzi. Természetesen a szolgálatok általános-speciális hatásköri, együttmüködési viszonyban állnak egymással ebben a tekintetben, melynek során a jogszabályok és közjogi szervezetszabályozó eszközök jelölik ki az egyes müködési területeket.

A munka oroszlánrésze a rendvédelmi szervek hatáskörébe tartozik, viszont - tekintettel arra, hogy egy komplex, többdimenziós hibrid intézkedéssorozat több lehetséges lépése (ir)reguláris katonai erők alkalmazásával járhat együtt, illetve az azt megelőző hírszerző tevékenység miatt, kiemelten a katonai objektumok (előzetes, titkos vagy leplezett) felmérésének szükségességére, valamint a szolgálatot teljesítő katonák esetleges befolyásolására ${ }^{36}$ az integrált katonai nemzetbiztonsági tevékenységet végző szolgálatnak ${ }^{37}$ kulcsszerepe van.

35 Szabó Károly: A katonai kémelhárítás feladatrendszerének új vonásai Európa és Magyarország megváltozott biztonsági környezetében. Felderítő Szemle, 2018/2., 186. https:/www.knbsz.gov.hu/hu/letoltes/fsz/2018-2.pdf (Letöltés időpontja: 2020. 05. 16.)

${ }^{36}$ Elég csak a Krím félsziget annektálásának előkészítő lépéseire gondolni.

${ }^{37}$ A témáról bővebben lásd Kovács József: A Katonai Nemzetbiztonsági Szolgálat az egyesítés után. A Nemzeti Közszolgálati Egyetemen 2012. május 24-én megrendezett Nemzetbiztonsági kihívások, nemzetbiztonsági szolgálatok című szakmai-tudományos konferencián elhangzott előadás szerkesztett változata. Hadtudomány, 2013/1-2., 87-90. http://www.mhtt.eu/hadtudomany/2013/1_2/HT_2013_1-2_mhtt.pdf (Letöltés időpontja: 2020. 05. 16.) 


\section{ÖSSZEGZÉS}

A nemzetbiztonsági aspektusból történő vizsgálat során az elmúlt évek katonai és politikai eseményeinek közismert és elfogadott magyarázatait - különösen a „színes forradalmakkal” és a Geraszimov-doktrínával ${ }^{38}$ összefüggésben - a megjelent elemzések tartalmát kellö kritikával érdemes kezelni. A történelem során sosem volt még olyan „sikeres és titkos” terv, amelyet a széles nyilvánosság számára a kivitelezői ennyire látványosan hozzáférhetővé tettek, kivéve azokat, amelyeket figyelemelterelésnek szántak. Kiváló eszköz lehet ugyanakkor a „doktrína kihirdetése” olyan esetben, amikor az a célja az intézkedést alkalmazó hatalomnak, hogy megteremtse annak látszatát, hogy bárhol bármi történik, az „lehet, hogy ennek a hatalomnak köszönhető". Így félelemben tarthat vele másokat, valamint elérheti ezzel a hibrid hadviselés egyes intézkedéseinek egyik legveszélyesebb célját, a kölcsönös bizalmatlanság állapotának megteremtését.

A kérdéskör helyes megközelítése az lehet, ha képesek vagyunk a „,lawfare”39 eszközrendszerét megfelelően használni. A , lawfare” kifejezést általa alkalmazott jelentése alapján Charles Dunlap így fogalmazta meg - a megítélésem szerint a hibrid kihívások elleni küzdelem egyik legjelentősebb - alapvetését: ,a hadviselést a »lawfare« váltja fel, és a párbajt inkább szavakkal, mint kardokkal vívják". ${ }^{40}$

Látni kell ugyanis, hogy a feladatban érintett szolgálatokat a jog(alkotás) eszközeivel is támogatni kell, ${ }^{41}$ továbbá szükséges megteremteni azt a fúziós központot is, amely képes biztosítani a különböző ágazatokat képviselő szervek, továbbá minden érintett (kormányzati és nem kormányzati) szereplő közötti koordinációt és kooperációt.

Ha sikerül megteremteni a feladatok ellátásához szükséges személyi, tárgyi és jogi feltételeket, akkor elvégezhető az eddig beazonosított idegen fenyegetések és az ezekhez kapcsolódó cselekmények elhárítása, később pedig a saját proaktív megoldások megvalósíthatóságára vonatkozó vizsgálatok végrehajtása. Ezek eredményeként versenyben maradunk, és később lehetőségünk lesz átszakítani a célszalagot is, még ha nem is elsőként.

Egy ilyen vizsgálat eredményeként merülhet fel a nemzeti stratégia kialakításának és egy szakosított kutatóközpontnak, illetve -csoportnak a kiépítése iránti igény, továbbá más, az ágazati tervezési folyamatok célirányos összehangolásának szükségességén alapuló intézkedés végrehajtása.

${ }^{38}$ Valerij Geraszimov: Cennoszty nauki v predvigyenii. Megjelent 2013. március 5-én Moszkvában, a Vojenno-promislennij kurjer 476. számának 1-2. oldalán. http://vpk-news.ru/sites/default/files/pdf/VPK_08_476.pdf (Letöltés időpontja: 2019. 05. 12.)

39 A „lawfare” kifejezés használatáról és jelentéséröl bővebben lásd Charles J. Dunlap: Law and Military Interventions: Preserving Humanitarian Values in 21 st Conflicts. 29. 11. 2001. http://people.duke.edu/ pfeaver/dunlap. pdf (Letöltés időpontja: 2019. 10. 31.). A kifejezés először az alábbi müben szerepel: John Carlson - Neville Yeomans: Whither Goeth the Law - Humanity or Barbarity, a The Way Out - Radical Alternatives in Australia (M. Smith \& D. Crossley, eds., Lansdowne, Melbourne, 1975, http://www.laceweb.org.au/whi.htm), ugyanakkor számos, eltérö jelentéssel használják. A tanulmány szempontjából a Dunlap által alkalmazott megközelítésében használom.

${ }^{40}$ Eredeti angol nyelven: „Lawfare replaces warfare and the duel is with words rather than swords.”

${ }^{41}$ A témáról bővebben lásd Hódos László: Gondolatok a gerilla-hadviselés elleni küzdelem egyes összefüggéseinek tudományos vizsgálatáról. Szakmai Szemle, 2019/3., 67-80. https://www.knbsz.gov.hu/hu/letoltes/ szsz/2019_3_szam.pdf(Letöltés időpontja: 2020. 05. 16.) 


\section{FELHASZNÁLT IRODALOM}

1995. évi CXXV. törvény a nemzetbiztonsági szolgálatokról. https://net.jogtar.hu/jogszabaly?docid= 99500125.tv

A 2019-2024-es időszakra szóló új stratégiai menetrend. Európai Tanács. https://www.consilium.europa.eu/media/39917/a-new-strategic-agenda-2019-2024-hu.pdf

Az Európai Parlamentnek és a Tanácsnak A hibrid fenyegetésekkel szembeni fellépés közös keretéről szóló közös közleménye. https://eur-lex.europa.eu/legal-content/HU/TXT/?uri=CELEX\%3A52016JC0018

Az Európai Unióról szóló szerződés és az Európai Unió működéséről szóló szerződés egységes szerkezetbe foglalt változata. 26. 10. 2012. https://eur-lex.europa.eu/legal-content/HU/TXT/?uri=celex\%3A12012E\%2FTXT

Béres János (szerk.): Külföldi nemzetbiztonsági szolgálatok. Zrínyi Kiadó, Budapest, 2018.

Carlson, John - Yeomans, Neville: Whither Goeth the Law - Humanity or Barbarity, a The Way Out - Radical Alternatives in Australia. Lansdowne, Melbourne, 1975. http://www.laceweb.org.au/ whi.htm

Caruso, Alfio: Da cosa nasce cosa Storia della mafia dal 1943 a oggi. Longanesi, Milano, 2005.

Dickie, John: Cosa Nostra - a history of the Sicilian Mafia. Hodder and Stoughton, London, 2004.

Dobák Imre: Nemzetbiztonsági szolgálatok - Betekintés a visegrádi országok (V4) nemzetbiztonsági rendszereibe. Hadtudomány, 2015/4., 113-130. https://epa.oszk.hu/02400/02463/00029/pdf/ EPA02463_hadtudomanyi_szemle_2015_04_113-130.pdf

Dunlap, Charles J.: Law and Military Interventions: Preserving Humanitarian Values in $21^{\text {st }}$ Conflicts. 29. 11. 2001. http://people.duke.edu/ pfeaver/dunlap.pdf

EU finance ministers: closer attention must be given to hybrid threats. 03. 09. 2019. Press release. https://eu2019.fi/en/article/-/asset_publisher/eu-n-valtiovarainministerit-hybridiuhkiin-kiinnitettava-enemman-huomiota

Farkas Ádám: A védelmi kötelezettségtöl a fegyveres védelem rendszeréig. Katonai Jogi és Hadijogi Szemle, 2018/1., 7-28. https://epa.oszk.hu/02500/02511/00008/pdf/EPA02511_katonai_jogi_ szemle_2018_1_007-028.pdf

Farkas Ádám: Az állam fegyveres védelmének alapvonalai. Budapest, Katonai Nemzetbiztonsági Szolgálat, 2019.

Farkas Ádám: Gondolatok az állam fegyveres védelmének lehetséges intézmény-fejlesztési irányairól. Katonai Jogi és Hadijogi Szemle, 2017/1-2., 103-124. http:/www.hadijog.hu/wp-content/uploads/2018/05/Katonai-szemle-2017-1-2.pdf

Finkelstein, Monte S.: Separatism, the Allies and the Mafia: The struggle for Sicilian Independence. Lehigh University Press, Cranbury, 1998.

Geraszimov, Valerij: Cennoszty nauki v predvigyenii. Megjelent 2013. március 5-én Moszkvában, a Vojenno-promislennij kurjer 476. számának 1-2. oldalán. http://vpk-news.ru/sites/default/files/ pdf/VPK_08_476.pdf

Dr. Héjja István: Nemzetbiztonsági szervezeti modellek. In: Dobák Imre (szerk.): A nemzetbiztonság általános elmélete. NKE Nemzetbiztonsági Intézet, Budapest, 2014, 57-72. http://m. ludita.uni-nke.hu/repozitorium/bitstream/handle/11410/8567/Teljes\%20sz\%c3\%b6veg\%21?sequence $=1 \&$ isAllowed $=\mathrm{y}$

Hódos László: Gondolatok a gerilla-hadviselés elleni küzdelem egyes összefüggéseinek tudományos vizsgálatáról. Szakmai Szemle, 2019/3., 67-80. https://www.knbsz.gov.hu/hu/letoltes/szsz/ 2019_3_szam.pdf 
Informal meeting of EU defence ministers, 28-29 August 2019, Helsinki. https://eu2019.fi/en/ events/2019-08-28/informal-meeting-of-eu-defence-ministers-

Informal meeting of ministers for economic and financial affairs (Ecofin) and Eurogroup. https:// eu2019.fi/en/events/2019-09-13/informal-meeting-of-ministers-for-economic-and-financial-affairs-ecofin-and-eurogroup

Joint Communication to the European Parliament, the European Council And the Council - Increasing resilience and bolstering capabilities to address hybrid threats. 13. 06. 2018. https://eeas.europa. eu/sites/eeas/files/joint_communication_increasing_resilience_and_bolstering_capabilities_to_ address_hybrid_threats.pdf

Kalvik, Jan: Secretary General at Aspen Security Forum: NATO is good for Europe and North America. Defence and Intelligence Norway, 19. 07. 2019. https://www.etterretningen.no/2019/07/19/ secretary-general-at-aspen-security-forum-nato-is-good-for-europe-and-north-america/

Kaputa László: Fejezetek a maffia történetéből. Szakmai Szemle, 2011/1., 23-57. https://www.knbsz. gov.hu/hu/letoltes/szsz/2011_1_szam.pdf

Keszely László: A védelmi igazgatás szerepe a nemzeti szintü átfogó megközelités megvalósitásában. Nemzeti Közszolgálati Egyetem, doktori értekezés, Budapest, 2017. https://nkerepo.uni-nke.hu/ xmlui/bitstream/handle/123456789/12398/ertekezes.pdf;jsessionid=6A54F0AA7F3328F7F72B10F4636C9506? sequence $=1$

DOI: $10.17625 /$ NKE.2017.31

Kovács József: A Katonai Nemzetbiztonsági Szolgálat az egyesités után. Hadtudomány, 2013/1-2., 87-90. http://www.mhtt.eu/hadtudomany/2013/1_2/HT_2013_1-2_mhtt.pdf

Kovács Krisztián: A befolyásolás szerepe a modern hadviselésben. Felsőfokú Nemzetbiztonsági Tanfolyam évfolyammunka, Nemzeti Közszolgálati Egyetem, Budapest, 2018.

Lakatos László - Varga Attila Ferenc: A magyar honvédelmi igazgatás. In: Farkas Ádám - Kádár Pál (szerk.): Magyarország katonai védelmének közjogi alapjai. Zrínyi Kiadó, Budapest, 2016, 159-211.

Lewis, Norman: The Honored Society. Collins, London, 1964.

Magyarország Alaptörvénye (2011. 04. 25.). https://net.jogtar.hu/jogszabaly?docid=a1100425.atv

Mgaloblishvili, Grigol - Kutelia, Batu - Guruli, Irina - Evgenidze, Nino: Hybrid warfare and the changing security landscape in the Euro-Atlantic area - political and economic implications. Economic NATO Research Paper No 1, Tbilisi, Georgia, 2016.

Sáfrán József: Az Amerikai Egyesült Államok és Magyarország nemzetbiztonsági szervezetrendszerének összehasonlitó elemzése. Felderítő Szemle, 2018/1., 71-87. https://www.knbsz.gov.hu/hu/ letoltes/fsz/2018-1.pdf

Szabó Károly: A katonai kémelháritás feladatrendszerének új vonásai Európa és Magyarország megváltozott biztonsági környezetében. Felderítő Szemle, 2018/2., 179-189. https://www.knbsz.gov. $\mathrm{hu} / \mathrm{hu} /$ letoltes/fsz/2018-2.pdf

Szentgáli Gergely: Csendben szolgálni, 1. rész: A magyar nemzetbiztonsági szektor helyzete és átalakitása 2010 és 2014 között. Hadtudomány, 2015/1-2., 44-56. http://www.mhtt.eu/hadtudomany/2015/1_2/2015_1_2_4.pdf

DOI: $10.17047 / \mathrm{HADTUD} \cdot 2015.25 .1-2.44$

Vida Csaba: Korszerü elemzö-értékelö eljárások alkalmazása a hírszerzésben. Hadtudomány, 2013/12., 77-86. http://www.mhtt.eu/hadtudomany/2013/1_2/HT_2013_1-2_mhtt.pdf

Work programmes. Europol, 04. 11. 2016. https://www.europol.europa.eu/publications-documents/ work-programmes 